\title{
The effect of international work experience on the career success of expatriates: a comparison of assigned and self-initiated expatriates.
}

\author{
Suutari, V., Brewster, C., Dickmann, M., Mäkelä, L., and C. Tornikoski (in press). Human \\ Resource Management.
}

\begin{abstract}
This paper examines the long-term effect of expatriation on careers, comparing the impact of international work experience on the career success of assigned and self-initiated expatriates. Our sample consists of employees who were working abroad in 2004 and we examine their subjective and objective career success eight years later. Despite the 'dark side of international careers' arguments associated with the repatriation literature, we find that the long-term impacts of international work experience on career success are generally positive and mainly unrelated to whether the work experience was acquired as an assigned or self-initiated expatriate. Companies recruit employees with international experience externally but are much more likely to offer further internal jobs to assigned expatriates. This reinforces the need for further research and for companies to see all those with international experience as important elements of the workforce.
\end{abstract}

\section{Key words:}

Careers; international work experience; career success; expatriates; self-initiated expatriates 


\section{INTRODUCTION}

International career researchers have increasingly been interested in establishing the effects of international work experience on careers. The early research, which often focused on the reintegration of assigned expatriates (AEs) back into the home organization after repatriation, argued fairly consistently that expatriation was not a career-enhancing move (Derr and Oddou, 1991; Forster, 1994; Harvey, 1989), albeit with considerable variation in the results across different studies. Recent studies (Kraimer, Shaffer and Bolino, 2009) report similar problems. The issues returning expatriates experience are created by a failure of the organization to value their acquired skills, the loss of status on the return home and reverse culture shock (Suutari and Brewster, 2003). Hamori and Koyuncu (2011) found that international work experience slows the ascent of executives to the top, an effect exacerbated by longer and repeat assignments.

It has been argued that the nature of careers has changed and companies may now value international work experience more than they did previously (Hamori and Koyuncu, 2011). Human capital theory predicts that developmental job experiences (such as international assignments) provide valuable learning that should have a positive impact on employees' long-term careers within and/or beyond their organizations ( $\mathrm{Ng}$, Eby, Sorensen and Feldman, 2005; Benson and Pattie, 2008; Kraimer et al., 2009). It may be that international work experience improves the opportunity to obtain a top management position ( $\mathrm{Ng}$ et al., 2005; Magnusson and Boggs, 2006) and a better salary (Daily, Certo and Dalton, 2000; Carpenter, Sanders and Gregersen, 2001). However, further research is clearly needed (Shaffer, Kraimer, Chen and Bolino, 2012: 1298; Cappellen and Janssens, 2005; Benson and Pattie, 2008; Hamori and Koyuncu, 2011). 
International work experience can be gained either within an employing organization or independently: i.e., through working abroad as an assigned expatriate (AE) or as a selfinitiated expatriate (SIE). AEs normally move to fill a position in a subsidiary of the same organization abroad (Suutari and Brewster, 2000) and much of the relevant literature indicates that their foreign assignments are driven by and connected to organizational and individual career and development considerations (Edström and Galbraith, 1977; Stahl, Miller and Tung, 2002; Bolino, 2007). Career structure seems to be highly important for AEs and there is some indication that their career progression can be faster than that of nonexpatriated peers (Doherty and Dickmann, 2012). In contrast, SIEs make their own way (Richardson and Mallon, 2005; Suutari and Brewster, 2000) and tend to work with a new employer abroad (Andresen, Bergdolt, Margenfeld and Dickmann, 2014). SIEs normally show substantial career agency. The career drivers of AEs and SIEs are distinct, with the former being much more motivated by objective career and development considerations (Doherty, Dickmann and Mills, 2011; Andresen, Biemann and Pattie, 2012). Intuitively, it seems likely that the career effects of their sojourn abroad will be different, raising the question: Are the impacts of international work experience on career success different between AEs and SIEs? Four issues are worth considering in examining this question.

The first is linked to the definition of career success, which was theoretically categorized as early as the 1930s into objective and subjective forms. Objective success was defined by Hughes $(1937,1958)$ as directly observable and measurable via attainments such as pay, promotions and occupational status that are verifiable by an impartial third party. Subjective success was based on the feelings experienced by the person engaged in his/her career (Heslin, 2005), usually measured, for instance, through job or career satisfaction. In expatriation in the managerial and professional spheres, the success of a career is often 
assessed on the basis of pay, promotion and occupational status. Consequently from the organizational viewpoint, the fact that an expatriate or employee leaves the organization after an international experience is usually seen as a failure by the organization. However, from the perspective of the individual, leaving an employer might be a logical career step. So whether an objective or subjective perspective is adopted affects the answer to our main question on the impact of international work experience on career success.

The second issue is the context in which an international experience is used after the assignment. That context has been shown to affect career success; for instance internal labour markets may work less than perfectly (Dickmann and Doherty, 2008) and international work experience may hinder career progress after the assignment (Benson and Pattie, 2008). We have known for some time that the proportion of AEs leaving their organization on repatriation is far higher than the normal turnover of their non-AE counterparts (Gregersen and Black, 1995). Given the investment in expatriates this may be considered inadequate human resource management. However, from an individual's viewpoint this may not look as bad, either in the short or longer-term, if it facilitates getting an interesting and challenging, or a higher paid, job with another company. Those who reach the peak of organizations (CEOs) and have international experience are more likely to be recruited externally (Daily et al., 2000), indicating that external markets may value such international experience more than internal job markets. So whether the international work experience is offered to, or valued by the internal labour market or the external one might affect views of career success.

The third issue is that career success might be perceived differently depending on when the evaluation is made. Most repatriation studies have explored outcomes over a relatively short time period after return (Benson and Pattie, 2008; Lazarova and Caligiuri, 2002; Suutari and 
Brewster, 2003) - this paper uses data collected several years after the expatriate experience. Predictions made on the basis of human capital theory may work better in the long run than immediately after repatriation as individuals have more time to get better integrated into job markets.

Fourth, the limited evidence we have on long-term careers tends to focus mainly on individuals whose careers have been successful from an objective career success perspective, such as CEOs (Daily et al., 2000; Hamori and Koyuncu, 2011). However, very few people reach such positions so our understanding will be enhanced by evidence from a more typical expatriate population (Kraimer et al., 2009), including those who have stayed abroad rather than repatriating (Suutari, Tornikoski and Mäkelä, 2012) and in particular, those who are selfinitiated expatriates (SIEs) (Al Ariss and Crowley-Henry, 2013).

The aim of this paper is to examine the impact of international work experience on the career success of AEs and SIEs a significant time after they gained their international experience. For this purpose we review the literature to first outline the evidence on the differences between international employees identified as AEs and SIEs. We use the research on these expatriate categories as a basis on which to develop a number of hypotheses related to expatriates' perceptions of their objective and subjective career success after the international work experience. We then explain our methodology, surveying highly qualified Finns with international work experience, before discussing our results. Finally, we present conclusions and explore the implications for researchers and practitioners.

This study makes several contributions to the literature. First, the study reports findings from an unusual long-term follow up survey of expatriate populations; answering calls for such 
research (Feldman and Ng, 2007; Shaffer et al., 2012) and extending our understanding of the long-term impact of international work experience on individuals' career success. Second, we add to the emerging wave of research on self-initiated expatriation by being the first to report on the long-term career impacts of such assignments and building on the research directly comparing career impacts for SIEs and AEs (e.g., Jokinen, Brewster and Suutari, 2008; Doherty et al., 2011; Peltokorpi and Froese, 2009). Third, we add to previous research by including AEs and SIEs who have changed their employer and those who have stayed abroad over a longer-term or returned to work abroad after initial repatriation. Finally, in order to obtain a richer view of the realities faced by international employees, the career success is analyzed both objectively and subjectively. In moving beyond theoretical insights, these nuanced insights allow us to develop an in-depth view of potential managerial implications.

\section{LITERATURE REVIEW AND HYPOTHESIS DEVELOPMENT}

Our review of the available literature focuses on expatriate careers in general and the differences in career between AEs and SIEs. Then, we examine some of the subjective and objective career outcomes of expatriation and establish pertinent hypotheses.

\section{Expatriate career success}

Generally speaking, a career is often presented as the sequence of a person's work experiences over time (Arthur, Hall, and Lawrence, 1989; Arthur, Khapova, and Wilderom, 2005) and career success can be seen as "the accomplishment of desirable work-related outcomes at any point in time in a person's work experiences over time" (Arthur et al., 2005: 179). Career success might be measured by objective factors such as promotions, salary level, or salary growth, or by organizational symbolic criteria such as a large office (Brousseau, Driver, Eneroth and Larsson, 1996). An alternative measure considers subjective factors such 
as career satisfaction (Ng et al., 2005; Shaffer et al., 2012), work-life balance (Finegold and Mohrman, 2001), or a sense of identity (Law, Meijers and Wijers, 2002). Both objective and subjective factors will be important to the person involved, and while interrelated, they are conceptually distinct.

Heslin (2005: 113) noted that "career success has long been a construct of considerable interest to career scholars ... and practitioners ..., not to mention the multitude of individuals engaged in a career (Hall, 1976, 2002)". Nevertheless, the literature on expatriate careers and particularly on career success is limited. A general presumption and occasional finding is that international work experience often has unhappy outcomes or is a risk in career terms (Richardson and Zikic, 2007: 181; Inkson, Gunz, Ganesh and Roper, 2012). We need a closer look at the impact of international work experience on longer term careers to be able to assess its value.

The short-term assessments of expatriate careers in the repatriation literature reinforce the notion that international work experience is not a good move in terms of objective career success, at least for AEs. Those assessments portray repatriated workers as having problems fitting back into their home organization (Riusala and Suutari, 2000; Stroh, Gregersen and Black, 1998). Between a quarter and a third of the assigned expatriates resigned on repatriation (Bolino, 2007; Kraimer, Shaffer, Harrison and Hong, 2012; Reiche, Kraimer and Harzing, 2011; Suutari and Brewster, 2003) while an even larger group seriously considers doing so (Caligiuri and Lazarova 2002; Suutari and Brewster 2003; Pate and Scullion, 2009). Negative effects on work and expatriates' concerns for the future have also been identified (Kraimer et al, 2009; Kohonen, 2008; Lazarova and Cerdin, 2007; Stahl and Cerdin, 2004). Bonache (2005) reports that repatriates felt worse about their career prospects than they did 
while on assignment and Benson and Pattie (2008) also argued that in terms of objective career success "the results are quite mixed with many studies finding that expatriates often experience underemployment ... or even demotions ...upon repatriation" (Shaffer et al., 2012: 1304).

Repatriation studies have examined the impact of the international work experience on an individual's career at, or soon after, the return home. However, many expatriates decide to continue working abroad even after the end of an initial assignment (Stahl and Cerdin, 2004; Jokinen et al., 2008) and among self-initiating expatriates, the figure is even higher (Cerdin and Le Pargneux, 2010; Andresen, Al Ariss, and Walther, 2013). International job markets can be expected to value international work experience more highly than domestic markets, although prolonged absence from the home country makes subsequent repatriation more difficult (Kraimer et al., 2009; Hamori and Koyuncu, 2011). To date, the academic research in this area has neglected to examine the career success of those who stay abroad or return to work overseas.

In contrast to the negative impact of international work on career success in the repatriation literature, most of the literature on career progression at the highest hierarchical levels indicates that international work experience has a positive impact on career success (Carpenter et al., 2001; Ng et al., 2005; Magnusson and Boggs, 2006). Hamori and Koyuncu (2011), however, report that international work experience has a negative impact on the speed at which people reach the top. The impact of international work experience on the careers of employees below the elite hierarchical level may be different. This perhaps reflects the difficulty of identifying such populations and of undertaking research on them. The evidence so far then is equivocal. The subjective or objective success of particular individuals pursuing 
careers involving international experience is likely to be influenced by a number of intersecting factors from their own perspectives and the ones used in the organizational and global environment (Cappellen and Janssens, 2005; Stevens, Oddou, Fuyura, Bird and Mendenhall, 2006; Tung and Lazarova, 2006).

A complete picture of whether international work experience is beneficial to the subjective and objective career evaluations of expatriates would ideally involve comparing careers including international work experience with careers that do not include any, but unfortunately access to such long-term follow-up data was not available. Thus the focus of the present study is on the comparison of the career success of two different types of expatriates, specifically, assigned expatriates and self-initiated expatriates.

\section{Contrasting the careers of AEs and SIEs}

The initial recognition of self-initiated expatriation among the international workforce identified SIEs as foreigners working in the host country, differentiated from the then traditionally-studied assigned expatriates by the fact that they make their own way to the job rather than being sent by their employer (Suutari and Brewster, 2000). A detailed definition of an array of international careers and experiences is given by Andresen et al., (2014). In some contexts, SIEs have been shown to be more numerous than AEs (Cerdin and Le Pargneux, 2010; Peltokorpi and Froese, 2009). However, since nearly all the early academic research had been done through business organizations and examined their employees on international assignment, SIEs largely escaped the notice of expatriation scholars. SIEs have always been part of the labour force but their importance may only have come to the fore when their numbers grew as a result of job markets becoming increasingly international, online recruitment systems making it easier and less costly to advertise jobs internationally 
plus increasing numbers of people gaining international work experience through travel, studying or working abroad. The opportunities to find a job abroad continue to grow and increasing numbers of employees consider this a realistic career option. It seems clear that SIEs are an important factor in today's global workforce (Tharenou and Caulfield, 2010) and are likely to become more so (Peiperl and Jonsen, 2007) and that international work experience will increasingly often be part of an individual's career.

Following the initial studies, research on SIEs expanded rapidly (Dorsch, Suutari and Brewster, 2012; Andresen et al., 2013; Vaiman and Haslberger, 2013). AEs are highly dependent on the career structures in organizations and benefit from career planning resulting in job offers at the repatriation stage (Dickmann and Doherty, 2010). SIEs are driven by different motivators which are less career and development oriented than AEs (Carr, Inkson and Thorn, 2005; Doherty et al., 2011). In turn, SIEs career paths are different from those of AEs (Peltokorpi and Froese, 2009). It has been argued that SIEs are much more career agentic (Andresen et al., 2013) and have a more protean (Hall, 1976) and boundaryless career (Bossard and Peterson, 2005; Stahl et al., 2002; Suutari, Brewster and Tornikoski, 2013). In other words, they are less interested in traditional careers and hierarchical advancement (Doherty et al., 2011). In addition, they seem to be less committed to a particular organization (Bossard and Peterson 2005; Stahl et al., 2002; Stahl and Cerdin 2004). Moreover, they may experience career problems on return to their home nation (Begley, Collings and Scullion, 2008). However, it has also been reported that their international work experience increases both their chances of promotion with their current employer and their marketability in the external market (Richardson and Mallon, 2005), both factors being indicators of objective career success. 
Unfortunately, with a few exceptions much of this research suffers from convenience sampling, small samples and an inability to identify response rates or to demonstrate representativeness. Shaffer et al., (2012: 1288) note that, while indicative, "almost all of the research ... has used cross-sectional designs".

Overall, the evidence available shows that the careers of AEs and SIEs are different, with AEs typically building stronger connections in the home country whereas SIEs are better connected in the host country (Mäkelä and Suutari, 2013), stay longer (Doherty et al., 2011), and are thus more likely to develop the essential language skills to advance their careers there. Some SIEs leave their home country due to a poor domestic job market situation (23\% in the Suutari and Brewster, 2000 study) and may have been in a weaker position on the job market before the assignment than their AE counterparts.

Here our focus is on the longer-term career impacts of international assignments and in particular, on the comparison of the career experiences of SIEs and AEs. The limited evidence available suggests that international work experience may be good for the individual careers of SIEs (Richardson and McKenna, 2003) and that it is at least as good for them as for AEs in terms of developing their career capital (Jokinen et al., 2008). There is little research but we might anticipate that the long-term career outcomes will be different, given the different starting points, with SIEs generally having no repatriation agreements, no homecountry unit to repatriate to and thus no career sponsorship from key personnel or a mentor in the home country. Probably, as a consequence, the SIEs' sojourn abroad tends to last longer than that of AEs and they tend to have more interest in forging more permanent global careers (Suutari and Brewster, 2000; Doherty et al., 2011). 


\section{Hypothesis development}

In order to develop a clearer understanding of the impact of expatriation on the career of AEs and SIEs, we explore measures of both subjective and objective career success. Starting with subjective career success, this is based on the individuals' perception of intrinsic rewards and the value they derive from their career (Suutari et al., 2012). We assess this in two pairs of markets: internal/external and home country/international. We also selected two different perspectives on subjective career success. First, studying perceived marketability increases our understanding of how former expatriates perceive the added value accruing from their international experience in the labour market (De Vos, De Hauw and Van der Heijden, 2011). Second, we used a more familiar career satisfaction measure to reveal how satisfied the individuals were with their careers several years after their expatriate assignment. The use of a career satisfaction perspective to future expatriation studies has been recommended by Hamori and Koyuncu (2011). With regard to objective career success, we considered two perspectives: the number of promotions the respondents had earned and whether the expatriates had job offers that led to a new job, seen here as evidence from beyond the expatriate indicating their marketability.

\section{Subjective career success: Perceived marketability in internal and external job markets}

Perceived marketability is defined as a person's belief that they are valuable to employers (Eby, Butts and Lockwood, 2003). Increasing our understanding of expatriates' views of their marketability provides a better understanding of their career behaviours, such as job turnover (Benson and Pattie, 2008; Takeuchi, Marinova, Lepak, and Lui, 2005).

Perceived marketability is typically divided into two different aspects: the individual's perception of their employability with the current employer (internal market) or with another employer (external market). For AEs the expatriate's own organization should be an 
immediate source of jobs at the end of the international assignment. Typically the people who chose them for the last assignment will serve as a 'bridge' back to the home organization while they are abroad (Dickmann and Doherty 2008). Furthermore, AEs can utilize the social capital they have both in the host country and in the home country when researching career options (Mäkelä and Suutari, 2013). Often, too, they will benefit from career structures and support mechanisms and practices to assist them in their careers (Collings, Doherty and Luethy, 2011). SIEs do not typically benefit from such organizational practices, neither from repatriation agreements nor specific plans about a future job (Andresen et al., 2013). SIEs tend to remain longer in their international jobs on average than AEs and thus their social connections to home-country job markets become weaker (Mäkelä and Suutari, 2013). Hence, due to structural and networking considerations we expect the AEs to see themselves as more marketable in their current employing organization after their assignment:

Hypothesis 1a. People whose international work experience was gained as an AE have higher internal marketability than people whose international work experience was gained as an SIE.

A substantial proportion of expatriates find themselves looking for new jobs at the end of (or even before the end of) their assignment (Suutari and Brewster, 2003; Vaiman and Haslberger, 2013). SIEs, in the vast majority of cases, will have to look for a new employer themselves if they want to repatriate. This may be a positive outcome from the perspective of the individual, if the external job market offers better opportunities (Suutari and Brewster, 2003). Both assignee groups will still be able to offer international work experience to the external job market, having had largely similar development opportunities (Jokinen et al., 2008). Therefore, we expect little difference in external marketability between the expatriate groups: 
Hypothesis $1 \mathrm{~b}$. There is no difference in external marketability between people whose international work experience was gained as an AE and people whose international work experience was gained as an SIE.

\section{Subjective career success: Perceived marketability in the home country versus international job markets}

Both SIEs and AEs might seek work in either the home country or the international job markets. These different career options have largely been ignored in international career research as investigations have focused on assigned repatriates who have stayed with the same employer and have decided to repatriate back to their home country (Bonache, 2005; Lazarova and Cerdin, 2007; Gregersen and Black, 1995). The marketability of an expatriate in the home and international (host or third country) economies, the differing opportunities in those markets and the extent to which those markets value international work experience, becomes significant. Since SIEs may have had less opportunity to establish meaningful contact with home organizations, have been out of the country for longer and may be less driven by career considerations (Doherty et al., 2011), they may work less hard towards a job upon return. They can, therefore, be expected to find it harder to land attractive jobs on repatriation than AEs would:

\footnotetext{
Hypothesis 2a. People whose international work experience was gained as an AE have higher perceived home-country marketability than people whose international work experience was gained as an SIE.
}

While domestic job markets may not always value international work experience, MNCs increasingly need internationally experienced people who have learned to work in a 
challenging and complex international business environment and/or are experienced in managing cross-cultural teams, so are capable of running international business operations abroad or handling other kinds of international responsibilities (Scullion and Collings, 2011; Sparrow, Farndale and Scullion, 2014). It has been argued that expatriates have opportunities as a result of the presumed global war for talent (McNulty, DeCieri, and Hutchings, 2013). Expatriates who seek job opportunities while on assignment are attractive to international headhunters and corporate recruiters and believe that their international work experience increases their marketability globally (McNulty et al., 2013; Suutari and Brewster, 2003). Among any random sample of expatriates, both SIEs and AEs, a considerable proportion will have had previous international assignment experience and many expatriates opt to continue in international career markets. The impact of choosing an international career market over the home-country market has been overlooked in previous international career research analyzing the career consequences of international mobility (Suutari et al., 2012). With such choices, marketability can be expected to be better than in the domestic job markets. However, this is likely to be the same for both AEs and SIEs since the international work experience is common to both and any differences in the type of previous assignment are unlikely to affect future marketability. While SIEs may be in a worse position in domestic job markets we do not expect this to hold in international markets. In the light of this, the following hypothesis is formed;
Hypothesis $2 \mathrm{~b}$. There is no difference in perceived international marketability between people whose international work experience was gained as an AE and people whose international work experience was gained as an SIE.

\section{Career satisfaction}


Career satisfaction has been suggested as an important future research area for expatriates (Hamori and Koyuncu, 2011). We noted above that SIEs may be disadvantaged in some career markets when compared to AEs due, for example, to the lack of SIE career structure support and repatriation agreements. We might expect AEs to have higher levels of career satisfaction than SIEs in the longer-term, despite the fact that many AEs are dissatisfied with their treatment immediately after their assignments. Furthermore, research has demonstrated a strong association between networks and career satisfaction (Kuijpers, Schyns, and Scheerens, 2006) and as AEs have stronger and more enduring intra-organizational homecountry networks both during and after their assignment, they are likely to experience greater career satisfaction than SIEs.

There are limitations to such rationalization, however, as subjective career views and objective career success are correlated but at the same time distinct concepts ( $\mathrm{Ng}$ et al., 2005). The more agentic behavior of SIEs may result in more general satisfaction in relation to their non-career drivers such as fulfilling their sense of adventure. The weaker intraorganizational networks of AES may be in turn to some extent be replaced by stronger networks of SIEs in the home country (Mäkelä and Suutari, 2013). While we recognize this limitation in the argument, we still anticipate that differences in employability and career success will feed through to career satisfaction:

Hypothesis 3. People whose international work experience was gained as an AE will have higher overall career satisfaction after the assignment than people whose international work experience was gained as an SIE.

\section{Objective career success: promotions}


While subjective career aspects are important, it is useful to complement personal perceptions with objective measures of the influence of international work experience on careers in order to obtain a broader view. While much of the existing research indicates that the short-term career impacts of corporate assignments are often negative, in the longer-term, the effect may be more positive (Doherty and Dickmann, 2012). We therefore expect that in the present study focusing on long-term careers, the findings will be more positive than has been reported in the context of repatriation (Benson and Pattie, 2008; Lazarova and Cerdin, 2007; Linehan and Scullion, 2002). Research indicating high turnover rates shortly following repatriation from assignments (Benson and Pattie, 2008) suggests it might often be necessary to change employer to find an organization that values international work experience more highly. Those staying with their original employer may find higher-level jobs more easily in the longer-term and those positions could utilize their international work experience. Therefore, it is important to study the number of promotions after the international work period (as an indicator for objective career success) in both situations, i.e., amongst those who have continued working with the same employer and for those who have changed their employer.

The growth of international competitiveness and awareness of the need for international mindsets within MNCs means that repatriates should benefit from improved promotion opportunities (Hamori and Koyuncu, 2011). Very little research focusing on SIEs' career development exists. But while there is some evidence that SIEs' professional development is seen as being positive (Jokinen et al., 2008), they still may face more limited opportunities in career development and hierarchical advancement than AEs. In the light of the above we expect that: 
Hypothesis 4. People whose international work experience was gained as an AE are promoted more often than people whose international work experience was gained as an SIE.

\section{Objective career success: Job offers (leading to a new job)}

One indicator of the marketability of individuals in job markets is whether they get job offers by proactive employers which lead to a new job after their international assignment. In these situations expatriates do not have to embark on a length job search. Within international career research it has been reported that it is common for AEs to get different kinds of job offers as this may be part of global career management or leadership development (Dickmann and Baruch, 2011). In addition, many SIEs and AEs change jobs and employers on the basis of such offers (Suutari et al., 2012). The alternative is that they have to become active and that they have to apply for jobs in competition with other people. SIEs are more likely to have to resort to their individual career agency in order to look for the next job (Andresen et al., 2013).

The importance of social connections to career success has been widely discussed in the literature. Social capital, referring to assets embedded in relationships, has become a popular framework in various research fields within the social sciences. Such social capital enables managers to do their work more effectively, as it facilitates access to knowledge and career opportunities (Kim, 2002; Lin, 2001). It has been argued that the importance of social capital increases with the extent of what is sometimes described as boundarylessness (Sturges, Guest and Mackenzie Davey, 2000) and expatriates are often claimed as archetypical boundaryless individuals (Stahl et al., 2002). Similarly the career capital framework (DeFillippi and Arthur, 
1994; Inkson and Arthur, 2001) emphasizes the importance of knowing-whom career capital for the career success of individuals.

The existing research also indicates that there are some differences in the social capital of AEs and SIEs. AEs can use existing networks of contacts in their home country to build host country networks as they already have a reputation in their firm and can identify and build key contacts more readily (Bozkurt and Mohr, 2011). Better quality internal networks are thus seen to give advantages to AEs since it is likely that they interact with more central, powerful business actors within the organization (Burt, Kilduff and Tasselli, 2013). Overall, AEs are likely to build more business contacts both at the head office and at their local operating unit than SIEs. Due to their social capital, it can be expected that AEs are better positioned than SIEs with regard to receiving internal job offers which lead to a new job after the assignment. As already discussed, it can be expected that in external job markets internationally experienced AEs and SIEs would be equally valued and thus we do not expect any difference between these groups with respect to whether they receive such external job offers. Due to the beneficial situation of AEs within their employer organization we expect the following difference between the groups:

Hypothesis 5. People whose international work experience was gained as an AE get their next job after the assignment through a job offer more often than people whose international work experience was gained as an SIE.

\section{METHODS}

\section{Sample}

The hypotheses were tested using data collected through an internet survey. The survey was carried out in co-operation with the Finnish Association of Business School Graduates (which represents Finnish business graduates with a university master's degree or higher). By 
adopting this approach we were able to obtain responses from both those AEs more typically found in surveys conducted only via employing organizations and from SIEs, while avoiding the weaknesses of opportunistic surveys conducted through general expatriate websites that are the source of much of the research on SIEs. Ideally, we would have included a control group of individuals who were similar to our respondents in all ways other than their international work experience, but this was not possible. Our responses are representative of the membership of the union and since union membership figures in the Nordic countries are among the highest in any country where trade union membership is not compulsory, it is likely that this group would be representative of all Finnish business graduates. The union was able to identify and follow up individuals who were working abroad in 2004 and we then sent them our questionnaire in 2012. This is another important benefit of surveys through this data source as other potential sources (employers, websites, etc.) have difficulty in following up respondents who may have left their employer, changed countries, or even retired. It is unlikely that any other source would permit the collation of such a representative database giving the contact information for 2012 of those who were expatriates - whether AEs or SIEs - in 2004.

The survey was circulated to 433 individuals. After one reminder, a total of 207 survey responses were returned. Four cases were deleted as incomplete or because they indicated multiple replies. The remaining 203 cases, $46.8 \%$ of the original mailing total, were accepted for further analysis. Among the respondents, 56\% were AEs, and the remainder SIEs. Other demographic information on the respondents is given in Table 1. Here the information is provided separately for AEs and SIEs in order to be able to compare these groups. 


\section{Measures}

In order to classify expatriates as SIEs or AEs as required by our hypotheses, the respondents were asked whether they a) had been sent abroad by their employer or b) had sought a job abroad on their own initiative.

Perceived marketability was measured by using four different scales. First, perceived internal marketability was measured by three items, (sample item: “After working abroad (in 2004), there were many opportunities available for me in my company"; Cronbach's alpha $=.734$ ) and perceived external marketability was also measured by three items (sample item: "After working abroad (in 2004), I obtained/could have easily obtained a comparable job with another employer"; Cronbach's alpha = .822) These scales were modified from Eby et al., (2003). The external marketability items were rewritten to differentiate perceived homecountry marketability (sample item: “After working abroad (in 2004), I obtained/could have easily obtained a comparable job in my home country": Cronbach's alpha $=.880$ ) and perceived international marketability (“After working abroad (in 2004), I obtained/could have easily obtained a comparable job in an international setting”: Cronbach's alpha $=.875$ ). Career satisfaction was measured by a 5-item scale taken from Greenhaus, Parasuraman and Wormley, 1990) (Sample item: "I am satisfied with the success I have achieved in my career": Cronbach's alpha .901). All items were measured on 5-point Likert scales.

The number of promotions after working abroad was measured by a single question: How many promotions you have gained since 2004? Responses were given as round numbers and were classified into three categories (no promotions; 1-2 promotions; more than 3 promotions). 
Job offers which led to a new job after the assignment were measured by a single question (relevant only for those who reported that they no longer worked in the same job as 2004): "If you have changed your job, how did you find the job?" Respondents answered the question by selecting one of the following alternatives: I found it myself/it was offered to me. A further question was asked about whether this job offer was received from the same employer or from other organizations.

\section{Controls}

We controlled for the impact of selected variables when testing the long-term differences in the career success of AEs and SIEs after their assignment. First, gender may affect the career impact of assignments (Caligiuri and Lazarova, 2002; Travik and Richardson, 2010). Second, the age of the assignee may have an effect since assignments in later career stages may be less influential for career success (Hamori and Koyuncu, 2011). Though the educational background of the respondents was the same, the nature of their tasks (e.g., production or marketing), might also affect their career opportunities (Hamori and Koyuncu, 2011). Fourth, the current location of the respondent (in the home country or abroad) could have a bearing on the perceived career consequences of the previous assignment. We also controlled for the respondent working for a public or private sector employer as the private sector may value international work experience more than the public sector.

\section{Analyses}

The differences between the AEs and SIEs were checked via $t$-tests and chi-square tests. In order to analyze the possible impacts of control variables, further regression analyses were performed (see Appendix 1). 


\section{FINDINGS}

Table 2 shows the career comparison of AEs and SIEs after their international work experience.

<<INSERT Table 2 ABOUT HERE >>

The results indicate that there is no significant difference between AEs and SIEs in the perceived internal marketability of respondents eight years after the first survey. Hypothesis 1a is thus not supported. The mean scores in Table 2 show the respondents are generally positive.

The results concerning perceived external marketability are similar to those for mobility within the organization, that is, there is no difference between the two groups of expatriates. Hypothesis $1 \mathrm{~b}$ was thus supported. The mean scores again indicate that perceived external marketability is seen in a positive light.

In addition to examining the traditional division between external and internal job markets, we analyzed the difference between home country and international job markets. In home country job markets we expected to see a difference between SIEs and AEs, but in the international market we did not. Our results (see Table 2) indicate there were no significant differences between the SIEs and AEs in terms of perceived home-country marketability, so Hypothesis 2a was not supported. The finding is similar for perceived international marketability, so Hypothesis $2 \mathrm{~b}$ was supported. As might be expected in the light of the international work experience of the group, the respondents saw their international marketability to be slightly better than their home-country marketability. This finding also 
supports the suggestion that it is important to differentiate between domestic and international job markets in international career research.

The results concerning career satisfaction are in line with the findings on marketability: There was no significant difference between the two groups of assignees. Thus, Hypothesis 3 was not supported. The findings indicate again that respondents were satisfied with their careers in 2012 .

Overall, the findings indicate that the type of the assignment did not make a difference to the expatriates' experiences on the impact of international work on subjective career success. Furthermore, these findings on subjective career experiences frame a more positive view of the career realities of international assignees of both types than the view apparent from the shorter-term repatriation studies. They have more resonance with the positive long-term career impacts of international assignment in the most successful CEO populations.

We then examined objective career success. First, we analyzed how many promotions AEs and SIEs have gained since their international work experience eight years earlier. The results indicate that there was no a significant difference between the AEs and SIEs in their upward career development in terms of number of promotions after their international work experience (Table 2), so Hypothesis 4 was supported. As can be seen from Table 2, in most cases the respondents had been promoted once or twice within the time frame; a minority had not been promoted at all, while around one fifth of the population in both respondent groups had been promoted three times or more during the previous eight years. 
Job offers which had led to a new job after the assignment were studied as a second indicator of objective career success. We explored if there was a difference between AEs and SIEs in receiving job offers which led to a new job. We included only those expatriates who reported that they have changed jobs since $2004(\mathrm{~N}=169)$ to the analysis. Our results show that AEs changed their job due to job offers more often (75\%) than SIEs (50\%) (see Table 2). Thus, hypothesis 5 was supported . Furthermore, our further analysis indicates that from these offers, $72 \%$ of AE job offers were internal compared to $47 \%$ for SIEs.

The results held in all cases when the control variables were added (see Appendix 1). In contrast to expectations, gender did not noticeably affect career success. In line with earlier findings (Hamori and Koyuncu, 2011), age during the assignment was found to impact negatively, but only on the perceived external marketability (both domestic and international) and promotions. The nature of tasks abroad had some influence but no systematic differences emerged. Those working in the private sector saw their internal, home country and international employability to be greater than those in the public sector and, probably reflecting these experiences, they also had higher levels of career satisfaction eight years later. Location in 2012 (home country or abroad) did not have a significant influence on career outcomes.

\section{DISCUSSION AND CONCLUSIONS}

The present study provides new evidence on the long-term career impact of international assignments among AEs and SIEs and takes into account the broad scale of career realities. It also includes various career perspectives such as perceived marketability, career satisfaction, promotions and job offers leading to a new job after the assignment. There have been few long-term studies of the effects of international work experience on careers and in particular, 
no such studies comparing AEs and SIEs could be found. By studying a representative sample of AEs and SIEs who had been abroad eight years previously, we were able to take an empirical and objective look at those effects. Because our sample was drawn from a comprehensive database covering most of those with university level business education in Finland, we were able to directly compare self-initiated and organizationally assigned expatriates and hence contribute to the growing literature on SIEs. We were able to assess careers from longer-term subjective and objective perspectives rather than just promotions or turnover soon after repatriation.

There has been much discussion of the career consequences of international assignments: the main findings are often presented as being rather negative even if there are some dissenting voices. Those findings were, however, drawn from evidence collected shortly after the repatriation of assigned expatriates and so do not fully reflect the reality of the international career environment, which includes SIEs and some people who will not repatriate as such, staying longer in the new country or moving on to another one. Nor can these findings from the repatriation studies tell us much about people who settle down in their home environment after a period of stress, or accept a job with another employer in their original host country or in other countries. Our evidence includes all these types.

Our findings support the predictions made on the basis of human capital theory that, given a longer time-scale, international work experience is good for a career both for AEs and SIEs (Ng et al., 2005; Benson and Pattie, 2008). The findings therefore support the evidence from research on CEOs that suggests people who reach the top often have international work experience. The previous literature which either used research conducted through companies or online surveys may have attracted more negatively minded respondents and a sprinkling of 
disappointed respondents is likely in any long-term career research, including the current sample. Overall, however, a distinctly positive view emerges from our research, whichever career measure is used. Our results show that career success does not differ significantly between AEs and SIEs, i.e., both expatriate types surveyed believe themselves highly marketable and are satisfied with their careers several years after their assignment. Furthermore, the results concerning the objective career success indicates that they have also had successful careers in the eyes of others. With regard to upward career development, the results indicated that both AEs and SIEs were equally often promoted.

The only significant difference between AEs and SIEs appeared when job changes after the assignment were analyzed. Here it appeared that three-quarters of AEs had secured their next job after the assignment on the basis of a job offer, whilst half of the SIEs had. These Finnish AEs were also more likely to get a job offer from Finland and in most cases that was from their current employer. Concomitantly, significantly more AEs had repatriated back to Finland than SIEs $(\chi 2(1)=17,087 * * *)$.

So, in line with the discussion on the literature, AEs seem to benefit more from their social capital within their employer organization. The literature tells us that SIEs have a different motivation for their working lives and seem to embark on different career journeys (Andresen et al., 2013; Vaiman and Haslberger, 2013). They may pursue a more holistic life experience when living abroad and are less driven by objective career progression considerations (Doherty et al., 2011). SIEs seem to assess career progression in terms other than merely moving up a hierarchy (Andresen et al., 2013). They may move, for example, just for adventure and challenge and be more concerned with issues like sustainability and well-being at work. In addition, they are less likely to benefit from organizational career management 
support than AEs are (Collings et al., 2011; McNulty et al., 2013) and they may also have a reduced potential for acquiring transferable capabilities and networks that could benefit their careers (Mäkelä and Suutari, 2013). Therefore, one would expect that SIEs might suffer negative career consequences such as enduring high risk, uncertainty and insecurity (Richardson and Mallon, 2005) and that there would accordingly be significant differences between the careers of AEs and SIEs.

However, in this representative sample, that is by and large not what we found. How are we to explain that? We suggest a range of reasons why the career outcomes of global work may be more similar between SIEs and AEs than hitherto suggested. Careers can be seen in a very general sense as a passage through life (Barley, 1989; Gunz and Peiperl, 2007) and our expatriates may have reflected on broad life dimensions when considering their career satisfaction, international work experience and marketability. This would imply that when we assess global careers we need to employ a broad theoretical perspective, concentrating on holistic factors, the dynamics of identity construction and psychological aspects such as selfconfidence and efficacy, while also incorporating the passage of time. While some concepts such as protean careers (Hall, 1976), intelligent careers (Arthur, Claman, and DeFillippi, 1995), or kaleidoscope careers (Mainiero and Sullivan, 2005) are more attuned to such investigations, other modern career approaches such as boundaryless careers (Arthur and Rousseau, 1996) or post-corporate careers (Peiperl and Baruch, 1997) focus less on these more holistic factors. One of our theoretical contributions, therefore, is to strengthen the emphasis on the holistic aspects of global careers over time. Explicitly incorporating this understanding into the various career theories and adjusting our investigations to the longterm career outcomes of AEs and SIEs accordingly is therefore important. 
Taking such a holistic, time- and context-sensitive view may also show that the two categories are not as separate as previously understood. While the focus of international career research on assigned expatriates has been on career impacts immediately after repatriation, it is important to note that a proportion of expatriates do not go home. They may spend some time at home and then return to an expatriate career; they may have a career that continues at home but includes another international assignment later in life; or they may continue in the international career market for many years. These possibilities are interrelated: globally minded individuals may choose to mix work cycles in the home country and abroad and may well mix AE and SIE assignments, with SIEs finding their next job as an $\mathrm{AE}$ and AEs discovering that, at least for a while, they prefer life abroad and opting to become SIEs. These are under-researched issues. In other words, whether a person goes abroad as an AE or an SIE, the long-term effects on his/her career are likely to be equally positive, perhaps because the development possibilities are similar for both groups (Jokinen et al., 2008). This finding is important when so many expatriates have taken their career into their own hands by leaving their home-country employer and heading abroad on their own initiative.

Modern career theory argues that individuals are masters of their own careers and that corporate career support is decreasing. It may be that AEs dissatisfied with their repatriation experience also look for external options and start acting in a more boundaryless manner. AEs who are generally more career driven (Doherty and Dickmann, 2012) and have better expatriation support, often including organizational career management, more frequently get internal job offers. In this sense, the career structure for AEs seems to encourage traditional career patterns. In contrast, SIEs less frequently gained job offers from their existing employer and, therefore, needed to be more agentic to gain new work. This reflects both the 
available career realities and their personal protean career orientation. Future qualitative research is therefore needed to further analyze the role of career structure and agency for SIEs and AEs, whether they act differently in different career markets how they react to the career structures within their organizational context, what sort of agentic behaviour is enacted in response to particular career contexts and to discern the effects of such activities on their careers.

Certain limitations should be borne in mind when interpreting our findings. First, our respondents were highly educated business professionals with international work experience. We were not able to compare the perceived career success of those with international work experience against those without it. Research that could do so would constitute a big step forward. Second, the evidence comes from a single country with a particularly highly educated, multi-lingual workforce and an international orientation. In smaller countries like Finland or many other European countries companies and the whole economy are also more dependent on international trade than in larger countries and thus international career moves and related competence development of expatriates may be more valued than in big countries with larger home markets such as the USA. Replication of the study in other institutional contexts would be valuable. Third, there is a real need for more studies that survey representative samples of complete categories of workers and for more studies of the careers of internationally mobile workers that cover a longer time period. It would also be worthwhile analyzing whether the career findings would be different if international job markets were further divided into the previous host country versus other foreign countries. SIEs tend to develop stronger networks in their host countries than AEs (Mäkelä and Suutari, 2013) and thus they may be in a better position to seek new jobs in the host country following the initial assignment. Finally, we do not have data on the country or countries to which the 
respondents were expatriated. There is an extensive debate about the impact of cultural and institutional distance and it may be that, for example, the effects on career of being relocated within the European Union are different from those of individuals whose careers took them to more distant countries. Whilst the impact on adjustment seems obvious, there does not seem to be any theoretical reason why there should be such an impact on career, but this is ripe for further empirical research. There is an exciting research agenda here and we look forward to more research of this kind in the future.

The practical implications for individuals include the fact that international work experience is good for the career. It makes little difference whether that experience is obtained as an assigned or a self-initiated expatriate. The repatriation literature shows that there may be issues on returning home, but our research shows that, over the longer-term, expatriates believe that the experience was beneficial for their careers and that they are likely to be promoted more than once within a decade of gaining their international work experience. If the opportunity is there, or if a person can create such an opportunity, they would be well advised to pursue it.

For MNEs, the advantages of identifying, monitoring and including SIEs as an important source of international knowledge and expertise are reinforced. Many self-initiated expatriates work with MNEs and they are a valuable part of the international labour force, bringing international knowledge, linguistic and cultural capabilities. Our data indicates that MNEs would do well to consider the attraction, selection and deployment of SIEs alongside the more traditional focus on AEs. Understanding the value of bringing SIEs into the workforce and how they may be used within the organization may not only save substantial costs but also increase effectiveness. In addition, our findings support the messages from the 
repatriation research that careful repatriation policies for both assigned and self-initiated expatriates that increase the retention among the group would pay dividends (Shen and Hall, 2009; Jassawalla and Sashittal, 2009). Developing and implementing wide-ranging strategies to pursue MNE goals through all sources of global staff can strengthen the international competitiveness of such organizations. 


\section{References}

Al Ariss, A. and Crowley-Henry, M. (2013). 'Self-initiated expatriation and migration in the management literature' Career Development International, 18:1, 78-96.

Andresen, M., Al Ariss, A. and Walther, M. (eds.) (2013). Self-initiated expatriation: mastering the dynamics, New York: Routledge.

Andresen, M., Bergdolt, F., Margenfeld, J. and Dickmann, M. (2014). ‘Addressing international mobility confusion - Developing definitions and differentiations for selfinitiated and assigned expatriates as well as migrants', International Journal of Human Resource Management, 25:16, 2295-2318.

Andresen, M., Biemann, T. and Pattie, M.W. (2012). 'What makes them move abroad? Reviewing and exploring differences between self-initiated and assigned expatriation', International Journal of Human Resource Management, 26:7, 932-947.

Arthur, M., Claman, P. and DeFillippi, R. (1995). 'Intelligent enterprise, intelligent careers', Academy of Management Perspectives, 9:4, 7-20.

Arthur, M., Hall, D. and Lawrence, B. (eds.) (1989). Handbook of career theory, Cambridge, UK: Cambridge University Press.

Arthur, M.B., Khapova, S.N. and Wilderom, C.P.M. (2005). 'Career success in a boundaryless career world', Journal of Organizational Behavior, 26:2, 177-202.

Arthur, M.B. and Rousseau, D.M. (1996). The boundaryless career: a new employment principle for a new organizational era, New York: Oxford University Press.

Barley, S. (1989). Careers, identities, and institutions: the legacy of the Chicago School of Sociology, in M. Arthur, D.T. Hall and B. Lawrence (eds.), Handbook of career theory, Cambridge, UK: Cambridge University Press. 
Begley, A., Collings, D.G. and Scullion, H. (2008). 'The cross-cultural adjustment of selfinitiated repatriates to the Republic of Ireland labour market', Employee Relations, 30:3, 264-282.

Benson, G.S. and Pattie, M. (2008). 'Is expatriation good for my career? The impact of expatriate assignments on perceived and actual career outcomes', International Journal of Human Resource Management, 19:9, 1636-1653.

Bolino, M.C. (2007). 'Expatriate assignments and intra-organizational career success: implications for individuals and organizations', Journal of International Business Studies, $38: 5,819-835$.

Bonache, J. (2005). 'Job satisfaction among expatriates, repatriates and domestic employees: the perceived impact of international assignments on work-related variables', Personnel Review, 34:1, 110-124.

Bossard, A.B. and Peterson, R.B. (2005). 'The repatriate experience as seen by American expatriates', Journal of World Business, 40:1, 9-28.

Bozkurt, O. and Mohr, T. (2011). 'Forms of cross border mobility and social capital in multinational enterprises', Human Resource Management Journal, 21:2, 138-155.

Burt, R.S., Kilduff, M. and Tasselli, S. (2013). 'Social network analysis: Foundations and frontiers on advantage', Annual Review of Psychology, 64, 527-547.

Brousseau, K.R., Driver, M.J.,Eneroth, K. and Larsson, R. (1996). 'Career pandemonium: realigning organizations and individuals', Academy of Management Perspectives, 10:4, $52-66$.

Caligiuri, P.M. and Lazarova, M. (2002). 'A model for the influence of social interaction and social support on female expatriates' cross-cultural adjustment', International Journal of Human Resource Management, 13:5, 761-772. 
Cappellen, T. and Janssens, M. (2005). 'Career paths of global managers: toward future research', Journal of World Business, 40:4, 348-360.

Carpenter, M., Sanders, G. and Gregersen, H. (2001). 'Bundling human capital with organizational context: the impact of international assignment experience on multinational firm performance and CEO pay', Academy of Management Journal, 44:3, 493-511.

Carr, S.C., Inkson, K. and Thorn, K. (2005). 'From global careers to talent flow: Reinterpreting 'brain drain', Journal of World Business, 40:4, 386-398.

Cerdin, J-L. and Le Pargneux, M. (2010). 'Career anchors: a comparison between organization-assigned and self-initiated expatriates', Thunderbird International Business Review, 52:4, 287-299.

Collings, D.G., Doherty, N. and Luethy, M. (2011). 'Understanding and supporting the career implications of international assignments', Journal of Vocational Behaviour, 78:3, 361371.

Daily, C.M., Certo, S.T. and Dalton, D.R. (2000). 'International experience in the executive suite: the path to prosperity', Strategic Management Journal, 21:4, 515-523.

DeFillippi, R.J. and Arthur, M.B. (1994). 'The boundaryless career: A competency-based perspective', Journal of Organizational Behavior, 15:4, 307-324.

De Vos, A., De Hauw, S., \& Van der Heijden, B. I. (2011). Competency development and career success: The mediating role of employability. Journal of Vocational Behavior, $79(2), 438-447$.

Derr, C. and Oddou, G. (1991). 'Are US multinationals adequately preparing future American leaders for global competition', International Journal of Human Resource Management, 2:2, 227-244. 
Dickmann, M. and Doherty, N. (2008). 'Exploring the career capital impact of international assignments within distinct organizational contexts', British Journal of Management, $19: 2,145-161$.

Dickmann, M. and Doherty, N. (2010). 'Exploring organisational and individual career goals, interactions and outcomes of international assignments', Thunderbird International Review, 52:4, 313-324.

Doherty, N. and Dickmann, M. (2012). 'Measuring the return on investment in international assignments: an action research approach', International Journal of Human Resource Management, 23:16, 3434-3454.

Doherty, N., Dickmann, M. and Mills, T. (2011). 'Exploring the motives of company-backed and self-initiated expatriates', International Journal of Human Resource Management, $22: 3,595-611$.

Dorsch, M., Suutari, V. and Brewster, C. (2012). 'Research on self-initiated expatriation: history and future directions', in M. Andresen, A. Al Ariss, M. Walther and K. Wolff (eds.), Self-initiated expatriation: mastering the dynamics, New York: Routledge.

Eby, L.T., Butts, M. and Lockwood, A. (2003). 'Predictors of success in the era of the boundaryless career', Journal of Organizational Behavior, 24:6, 689-708.

Edström, A. and Galbraith, J. R. (1977). 'Transfer of managers as a coordination and control strategy in multinational organizations', Administrative Science Quarterly, 22:2, 248-263.

Feldman, D.C., and Ng, T.W.H. (2007). 'Careers: mobility, embeddedness and success', Journal of Management, 33:3, 350-377.

Finegold, D. and Mohrman, S.A. (2001). 'What do employee really want? The perception vs. the reality', paper presented at the meeting of the World Economic Forum, Davos, Switzerland. 
Forster, N. (1994). 'The forgotten employees? The experiences of expatriate staff returning to the UK', International Journal of Human Resource Management, 5:2, 405-425.

Greenhaus, J. H., Parasuraman, S., \& Wormley, W. M. (1990). Effects of race on organizational experiences, job performance evaluations, and career outcomes. Academy of Management Journal, 33(1), 64-86.

Gregersen, H. and Black, J. (1995). 'Keeping high performers after international assignments: a key to global executive development', Journal of International Management, 1:1, 3-21.

Gunz, H. and Peiplerl, M. (2007). 'Introduction', in H. Gunz and M.A. Peiplerl (eds.), Handbook of Career Studies, London: Sage Publications.

Hall, D.T. (1976). Careers in Organizations, Pacific Palisades, CA: Goodyear.

Hamori, M. and Koyuncu, B. (2011). 'Career advancement in large organizations in Europe and the United States: do international assignments add value', International Journal of Human Resource Management, 22:4, 843-862.

Harvey, M. (1989). 'Repatriation of corporate executives: an empirical study', Journal of International Business Studies, 20:1, 131-144.

Heslin, P.A. (2005). 'Conceptualizing and evaluating career success', Journal of Organizational Behavior, 26:2, 113-136.

Hughes, E. C. (1937). Institutional office and the person. American Journal of Sociology, 404-413.

Hughes, E. C. (1958). Men and their work. New York: Free Press.

Inkson, K. and Arthur, M.B. (2001). 'How to be a successful career capitalist', Organizational Dynamics, 30:1, 48-61.

Inkson, K., Gunz, H., Ganesh, S. and Roper, J. (2012). 'Boundaryless careers: bringing back boundaries', Organization Studies, 33:3, 323-340. 
Jokinen, T., Brewster, C. and Suutari, V. (2008). 'Career capital during international work experiences: contrasting self-initiated expatriate experiences and assigned expatriation', International Journal of Human Resource Management, 19:6, 978-998.

Kim, Y. (2002). 'Executive Social Capital and Its Impacts on Job Promotion', Academy of Management Proceedings, 2002, Best Paper Series, J1.

Kohonen, E. (2008). 'The impact of international assignments on expatriates' identity and career aspirations: reflections upon re-entry', Scandinavian Journal of Management, 24:4, 320-329.

Kraimer, M.L., Shaffer, M.A. and Bolino, M.C. (2009). 'The influence of expatriate and repatriate experiences on career advancement and repatriate retention', Human Resource Management, 48:1, 27-47.

Kraimer, M.L., Shaffer, M.A., Harrison, D.A. and Ren, H. (2012). 'No place like home? An identity strain perspective on repatriate turnover', Academy of Management Journal, $55: 2,399-420$.

Kuijpers, M., Schyns, B. and Scheerens, J. (2006). 'Career competencies for career success', Career Development Quarterly, 55:2, 168-178.

Law, B, Meijers, F. and Wijers, G. (2002). 'New perspectives on career and identity in the contemporary world', British Journal of Guidance and Counselling, 30:4, 431-449.

Lazarova, M. and Caligiuri, P.M. (2002). 'Retaining repatriates: the role of organizational support practices', Journal of World Business, 36:4, 389-401.

Lazarova, M. and Cerdin, J.-L. (2007). 'Revisiting repatriation concerns: organizational support versus career and contextual influences', Journal of International Business Studies, 38:3, 404-429.

Lin, N. (2001). Social capital: a theory of social structure and action, Cambridge: Cambridge University Press. 
Linehan, M. and Scullion, H. (2002). 'Repatriation of European female corporate executives: an empirical study', International Journal of Human Resource Management, 13:2, 254267.

Magnusson, P. and Boggs, D.J. (2006). 'International experience and CEO selection: an empirical study', Journal of International Management, 12:1, 107-125.

Mainiero, L. and Sullivan, S. (2005). The opt-out revolt: why people are leaving companies to create kaleidoscope careers, Palo Alto, CA: Davies-Black Publishing.

Mäkelä, K. and Suutari, V. (2013). ‘Social capital of traditional and self-initiated expatriates', in V. Vaiman and Haslberger, A. (eds.), Managing talent of self-initiated expatriates: $a$ neglected source of the global talent flow, London: Palgrave Macmillan.

McNulty, Y., De Cieri, H. and Hutchings, K. (2013). 'Expatriate return on investment in the Asia Pacific: an empirical study of individual ROI versus corporate ROI', Journal of World Business, 48:2, 209-221.

Ng, T.W.H., Eby, L.T., Sorensen, K.L. and Feldman, D.C. (2005). 'Predictors of objective and subjective career success: a meta-analysis', Personnel Psychology, 58:2, 367-408.

Pate, J., \& Scullion, H. (2009). The changing nature of the traditional expatriate psychological contract. Employee Relations, 32(1), 56-73.

Peiperl, M. and Baruch, Y. (1997). 'Back to square zero: the post-corporate career', Organizational Dynamics, 25:4, 7-22.

Peiperl, M.A. and Jonsen, K. (2007). 'Global careers', in P.H. Gunz and M.A. Peiperl (eds.), Handbook of Career Studies, London: Sage Publications.

Peltokorpi, V. and Froese, F.J. (2009). 'Organizational expatriates and self-initiated expatriates: who adjusts better to work and life in Japan?', International Journal of Human Resource Management, 20:5, 1096-1112. 
Reiche, B.S., Kraimer, M.L. and Harzing, A.-W. (2011). 'Why do international assignees stay? An organizational embeddedness perspective', Journal of International Business Studies, 42:4, 521-544.

Richardson, A.M. and Mallon, M. (2005). 'Career interrupted? The case of the self-directed expatriate', Journal of World Business, 40:4, 409-420.

Richardson, J. and McKenna, S. (2003). 'International experience and academic careers: what do academics have to say?', Personnel Review, 32:6, 774-795.

Richardson, J. and Zikic, J. (2007). ‘The darker side of an international career', Career Development International, 12:2, 164-186.

Riusala, K. and Suutari, V. (2000). 'Expatriation and careers: Perspectives of expatriates and spouses', Career Development International, 5:2, 81-90.

Scullion, H. and Collings, D. (eds) (2011). Global Talent Management, London: Routledge.

Shaffer, M.A., Kraimer, M.L., Chen, Y.-P., and Bolino, M.C. (2012). 'Choices, challenges, and career consequences of global work experiences: a review and future agenda', Journal of Management, 38:4, 1282-1327.

Shen, Y. and Hall, D.T. (2009) 'When expatriates explore other options: Retaining talent through greater job embeddedness and repatriate adjustment', Human Resource Management, 48:5, 793-816.

Sparrow, P., Farndale, E. and Scullion, H. (2014). 'Globalizing the HR architecture: the challenges facing corporate HQ and international-mobility functions', in P. Sparrow, H. Scullion and I. Tarique, Strategic Talent Management: Contemporary Issues in International Context, Cambridge: Cambridge University Press.

Stahl, G. and Cerdin, J-L. (2004). 'Global careers in French and German multinational corporations', Journal of Management Development, 23:9, 885-902. 
Stahl, G.K., Miller, E.L. and Tung, R.L. (2002). 'Toward the boundaryless career: a closer look at the expatriate career concept and the perceived implications of an international assignment', Journal of World Business, 37:3, 216-227.

Stevens, M.J., Oddou, G., Fuyura, N., Bird, A. and Mendenhall, M. (2006). 'HR factors affecting repatriate job satisfaction and job attachment for Japanese managers', International Journal of Human Resource Management, 17:5, 831-841.

Stroh, L.K., Gregersen, H.B. and Black, J.S. (1998). 'Closing the gap: expectations versus reality among expatriates', Journal of World Business, 33:2, 111-124.

Sturges, J., Guest D. and Mackenzie Davey, K. (2000). 'Who’s in charge? Graduates' attitudes to and experiences of career management and their relationship with organisational commitment', European Journal of Work and Organisational Psychology, $9: 3,351-370$.

Suutari, V. and Brewster, C. (2000). 'Making their own way: international experience through self-initiated foreign assignments', Journal of World Business, 35:4, 417-436.

Suutari, V. and Brewster, C. (2003). 'Repatriation: empirical evidence from a longitudinal study of careers and expectations among Finnish repatriates', International Journal of Human Resource Management, 14:7, 1132-1151.

Suutari, V., Brewster, C. and Tornikoski, C. (2013). 'The careers of self-initiated expatriates', in V. Vaiman and H. Haslberger (eds.), Talent management of self-initiated expatriates, London: Palgrave Macmillan.

Suutari, V., Tornikoski C. and Mäkelä, L. (2012). 'Career decision making of global careerists', International Journal of Human Resource Management, 23:16, 3455-3478.

Takeuchi, R., Marinova, S. V., Lepak, D. P. and Liu, W. (2005). 'A model of expatriate withdrawal-related outcomes: decision making from a dualistic adjustment perspective', Human Resource Management Review, 15:2, 119-138. 
Jassawalla, A. R., \& Sashittal, H. C. (2009). Thinking strategically about integrating repatriated managers in MNCs. Human Resource Management, 48(5), 769-792.

Tharenou, P. and Caulfield, N. (2010). 'Will I stay or will I go? Explaining repatriation by self-initiated expatriates', Academy of Management Journal, 53:5, 1009-1028.

Travik, L.E.M. and Richardson, A.M. (2010). 'Career success for international professional women in the land of the equal? Evidence from Norway', International Journal of Human Resource Management, 21:15, 2798-2812.

Tung, R.L. and Lazarova, M.B. (2006). 'Brain drain versus brain gain: an exploratory study of ex-host country nationals in Central and East Europe', International Journal of Human Resource Management, 17:11, 1853-1872.

Vaiman, V. and Haslberger, H. (2013). Talent management of self-initiated expatriates, London: Palgrave Macmillan. 
Table 1. Demographic information on the sample

\begin{tabular}{|c|c|c|c|}
\hline & All & AEs & SIEs \\
\hline Gender (male) & $134(67.7 \%)$ & $82(73.9 \%)$ & $52(60.5 \%)$ \\
\hline Age at 2004 & $\mathrm{M}=41.97, \mathrm{SD}=9.45$ & $\mathrm{M}=41.98, \mathrm{SD}=9.47$ & $\mathrm{M}=41.81, \mathrm{SD}=9.46$ \\
\hline In a relationship in 2004 & $163(80.3 \%)$ & $93(82.3 \%)$ & $69(77.5 \%)$ \\
\hline Accompanied by family & $137(85.1 \%)$ & $82(89.1 \%)$ & $54(79.4 \%)$ \\
\hline Finnish employer & $102(51.0 \%)$ & $79(69.9 \%)$ & $23(26.4 \%)$ \\
\hline Private sector employer & $175(86.6 \%)$ & $107(94.7 \%)$ & $68(76.4 \%)$ \\
\hline $\begin{array}{l}\text { On which kind of tasks } \\
\text { did you work in } 2004 ?\end{array}$ & & & \\
\hline $\begin{array}{l}\text { General management } \\
\text { tasks }\end{array}$ & $48(24.1 \%)$ & $28(25.0 \%)$ & $20(23.0 \%)$ \\
\hline Economic tasks & $61(30.7 \%)$ & $41(36.6 \%)$ & $20(23.0 \%)$ \\
\hline Marketing tasks & $40(20.1 \%)$ & $27(24.1 \%))$ & $13(14.9 \%)$ \\
\hline $\begin{array}{l}\text { Data processing/ } \\
\text { ICT-tasks }\end{array}$ & $6(3.0 \%)$ & $4(1.8 \%)$ & $4(4.6 \%)$ \\
\hline Other $^{1}$ & $44(22.1 \%)$ & $14(12.5 \%)$ & $30(34.5 \%)$ \\
\hline
\end{tabular}

${ }^{1}$ Other includes a number of different roles such as teaching, consulting, and entrepreneur. 
Table 2. Career success of AEs and SIEs

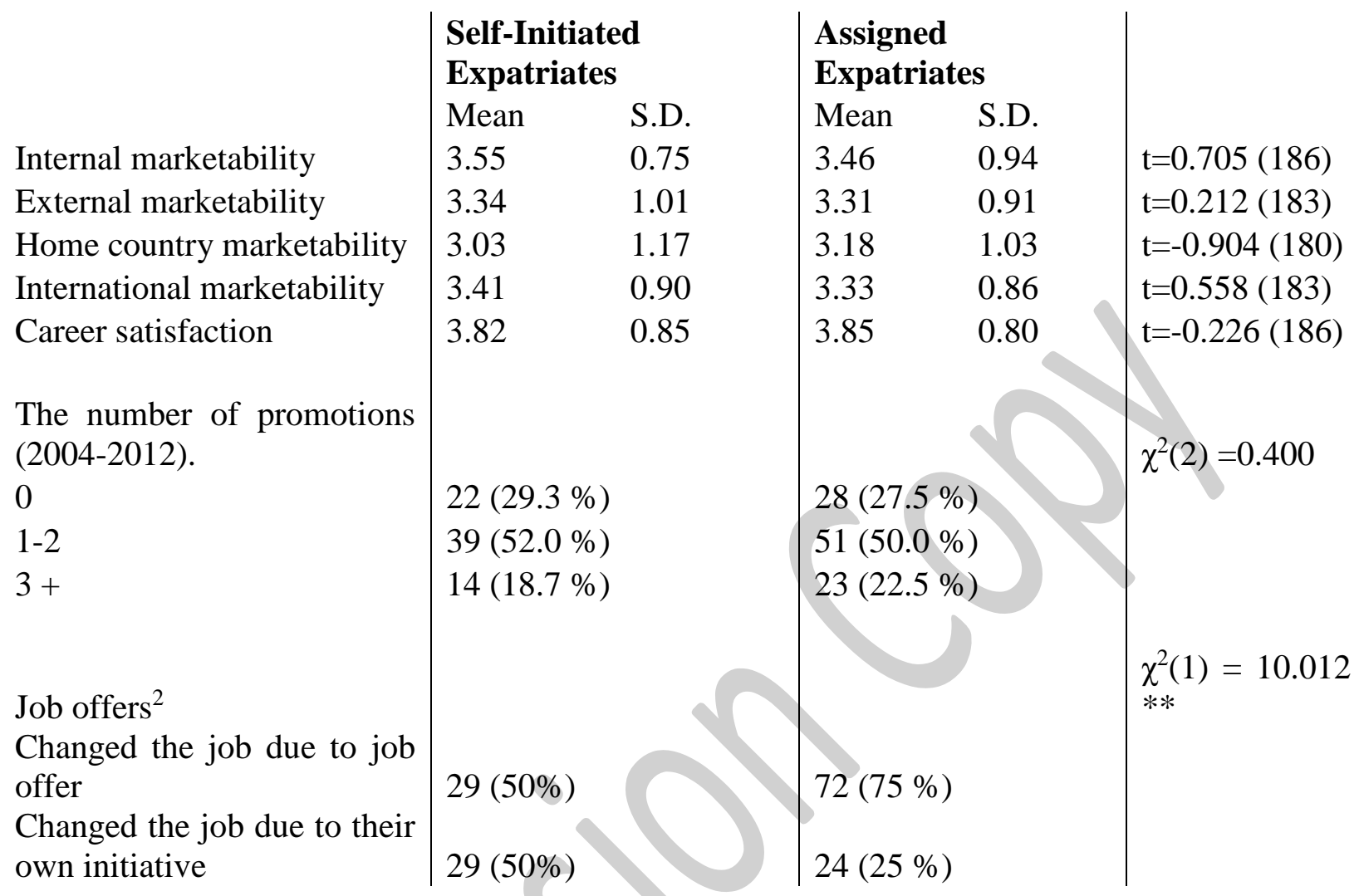

${ }^{2}$ Analysed only among them who have changed the job after $2004(\mathrm{~N}=169)$. 
Appendix 1. Testing the effect of control variables

\begin{tabular}{|c|c|c|c|c|c|c|c|}
\hline & $\begin{array}{l}\text { Internal } \\
\text { marketability }\end{array}$ & $\begin{array}{l}\text { External } \\
\text { marketability }\end{array}$ & $\begin{array}{l}\text { Home country } \\
\text { marketability }\end{array}$ & $\begin{array}{l}\text { International } \\
\text { marketability }\end{array}$ & $\begin{array}{l}\text { Career } \\
\text { satisfaction }\end{array}$ & $\begin{array}{l}\text { Number of } \\
\text { promotions }\end{array}$ & Job offers \\
\hline \multirow[t]{2}{*}{$\mathrm{N}$} & 203 & 203 & 203 & 203 & 203 & 203 & 169 \\
\hline & $\mathrm{B}$ & $\mathrm{B}$ & $\mathrm{B}$ & $\mathrm{B}$ & $\mathrm{B}$ & $\operatorname{Exp}(B)$ & $\operatorname{Exp}(B)$ \\
\hline Intercept & $2.626 * * *$ & $4.522 * * *$ & $3.918 * * *$ & $4.169 * * *$ & $2.920 * * *$ & $11.188 * * *$ & 4.767 \\
\hline Type of expatriation (SIE vs. AE) & 0.142 & 0.068 & -0.037 & 0.004 & 0.039 & 0.864 & $0.324 * * *$ \\
\hline Gender (male vs. female) & 0.156 & 0.101 & -0.085 & 0.115 & 0.154 & 1.168 & 1.169 \\
\hline Age in 2004 & 0.002 & $-0.030 * *$ & $-0.031 * *$ & $-0.028 * * *$ & 0.009 & $0.957 * * *$ & 0.983 \\
\hline $\begin{array}{l}\text { Worked in general management tasks } \\
\text { in } 2004\end{array}$ & Reference level & Reference level & Reference level & Reference level & Reference level & Reference level & Reference level \\
\hline Worked on economic tasks in 2004 & $0.696 * * *$ & -0.147 & 0.134 & -0.006 & 0.111 & 1.225 & 0.643 \\
\hline Worked on marketing tasks in 2004 & 0.126 & -0.363 & -0.205 & 0.140 & 0.012 & 1.375 & 2.114 \\
\hline Worked on other tasks in 2004 & 0.322 & -0.266 & 0.068 & 0.389 & -0.066 & 1.116 & 1.082 \\
\hline $\begin{array}{l}\text { Sector of employer organization in } \\
2004 \text { (private vs. public) }\end{array}$ & $0.529 *$ & 0.445 & $0.683 *$ & $0.602 *$ & $0.508 *$ & 0.902 & 1.745 \\
\hline $\begin{array}{l}\text { Location in } 2012 \text { (in home country vs. } \\
\text { abroad) }\end{array}$ & $-0.323 *$ & -0.115 & & $-0.285 *$ & -0.266 & 0.960 & 0.740 \\
\hline $\mathrm{R}^{2}$ & .156 & .124 & .157 & .152 & .094 & - & - \\
\hline
\end{tabular}

Note. The table shows linear regression coefficients (B), except for the number of promotions where exp(B) is presented as the multiplicative term of the poisson and logistic regression models.

Significance levels: $* \mathrm{p}<.05, * * \mathrm{p}<.01, * * * \mathrm{p}<.001$. 